\title{
MATERI KOMPETENSI MATEMATIKA LULUSAN SMK DAN KEBUTUHAN DUNIA INDUSTRI
}

\section{(THE SUBJECT MATHEMATICAL COMPETENCY OF VOCATIONAL EDUCATION AND INDUSTRIES NEEDS)}

\author{
Nena Restiana ${ }^{1,2}$, Maman Fathurrahman ${ }^{2}$, Hepsi Nindiasari ${ }^{2}$ \\ ${ }^{1}$ PT. Krakatau Steel (Persero), Tbk, resti.nena@gmail.com \\ ${ }^{2}$ Dosen Pendidikan Matematika, Universitas Sultan Ageng Tirtayasa
}

\begin{abstract}
Abstrak
Penelitian ini bertujuan untuk mendeskripsikan kesenjangan implementasi materi matematika sekolah menengah kejuruan (SMK) yang terjadi antara dunia pendidikan dan dunia industri. Metode pendekatan yang digunakan dalam penelitian ini adalah deskriptif kuantitatif dengan wawancara, observasi dan dokumentasi kepada SMK dan empat industri baja yang beroperasi di Kota Cilegon. Hasil yang didapatkan adalah kemampuan matematika di dunia pendidikan yang meliputi berbagai materi yang diajarkan di SMK hanya beberapa digunakan dalam dunia industri. Sedangkan untuk industri baja hanya sebatas pada penggunaan angka dan logika matematika. Hal tersebut dikarenakan pekerjaan level pelaksana masih terbatas pada instruksional dan berdasarkan pada standar prosedur yang sudah ditetapkan oleh superior.
\end{abstract}

Kata Kunci: Kesenjangan, Matematika, SMK

\begin{abstract}
This study aims to describe the gap between the implementation of content of vocational education mathematics and the industrial practises. This study use quantitative descriptive method with the interviews, observation and documentation on two vocational education and four steel industries in Cilegon. The results obtained are mathematical abilities in vocational education which include various content material taught, only a few content are used in the industrial practises. Especially, implementation of mathematics content on the steel industry is only limited to mathematical logic and numbers usage. This is because work level implementers are still limited to instructional and based on standard procedures that have been set by the superior.
\end{abstract}

Key words: Gap, Mathematic's content, Vocational, Education

\section{PENDAHULUAN}

Kesenjangan kompetensi pendidikan dan dunia kerja menjadi problematika tersendiri pada setiap generasi dan setiap Negara. Berbagai penelitian berupaya untuk menganalisis kesenjangan yang terjadi antara pendidikan dengan dunia kerja (seperti Agus, Awang, Yussof, \& Makhbul, 2011) dan berupaya untuk menjembatani kesenjangan tersebut melalui kerjasama antar 
sekolah, industri dan pemerintah dalam rangka meningkatan keahlian lulusan (Ayonmike \& Okeke, 2016).

Kompetensi matematika diartikan sebagai penalaran dan pemecahan masalah dengan pendekatan matematis yang meliputi kemampuan, kecakapan kesanggupan siswa dalam menarik kesimpulan atau membuat sebuah pernyataan (Zaenab, 2015). Penalaran matematis sangat penting bagi siswa dikarenakan dapat mendukung pemahaman siswa atas makna dari sebuah materi yang disampaikan (Fajriyah, Nugraha, Akbar, \& Bernard, 2015). Hal tersebut yang mendorong beberapa penelitian dilakukan untuk meningkatkan kemampuan berpikir matematis (Apino \& Retnawati, 2017; Nindiasari, Kusumah, Sumarmo, \& Sabandar, 2014; Ahmad \& Shahrill, 2014; Saragih \&Winmery L. Habeahan, 2014; Calao, Moreno-Le'on, Correa, \& Robles, 2015).

Kesenjangan kompetensi juga terjadi pada kemampuan matematika. Menurut AAMT (2014) bahwa kesenjangan (miss match) juga terjadi pada kemampuan matematika antara di sekolah dengan tempat kerja dimana matematika di tempat kerja lebih kompleks, kontekstual dan melibatkan berbagai faktor seperti tim yang terlibat dan kondisi lapangan. Williams, Wake, \& Boreham (2001) menjelaskan bahwa kesenjangan matematika sekolah dan di tempat kerja ditemukan dalam penggunaan grafik, satuan dan menulis angka dengan cara yang berbeda, meskipun di sekolah hal tersebut dikategorikan sebagai kemampuan matematika yang jarang digunakan. FitzSimons (2014) mempertegas bahwa pendidikan matematika lebih fokus kajian vertikal/teoritis, sehingga hal tersebut meyebabkan kurangya pemahaman kemampuan matematika pada aspek horizontal/kontekstual.Penelitan tersebut memang masih menjelaskan kesenjangan kemampuan matematika secara umum dan belum menjelaskan lebih detail dari kemampuan matematika. Oleh karena itu rekomendasi yang dimunculkan adalah diperlukan perubahan kurikulum yang mampu menjadikan siswa lebih adaptif dalam menggunakan matematika pada kondisi yang baru namun tidak secara spesifik kemampuan apa yang perlu dikembangkan.

Berdasarkan pada latar belakang tersebut, masih sedikit penelitian yang memaparkan kesenjangan kemampuan matematika antara dunia pendidikan dan dunia kerja secara spesifik pada bidang kajian dalam hal ini adalah matematika. Dengan demikian, penelitian ini akan mengisi celah tersebut yaitu dengan melakukan kajian mengenai kompetensi matematika pada dunia pendidikan dan dunia industri sehingga menjadi jembatan penghubung antara dunia pendidikan dan dunia industri dalam menyediakan calon pekerja yang memiliki kompetensi sesuai dengan kebutuhan dunia pendidikan.

\section{KAJIAN TEORI \\ Profil Pendidikan SMK}

Secara hirarki SMK berada di atas SMP (Sekolah Memengah Pertama) dan di bawah sekolah vokasional diploma (D1, D2, D3 dan D4), atau Strata (S1) dimana siswa lulusan SMK dapat melanjutkan studi sesuai dengan pilihan tingkatan selanjutnya. Program pendidikan SMK adalah program pendidikan tingkat menengah yang berfokus kepada penguatan pendidikan vokasional dengan tujuan mempersiapkan lulusan yang tidak melanjutkan kejenjang pendidikan tinggi untuk lebih siap masuk dunia kerja sesuai dengan kompetensi yang dimiliki pada bidangnya. SMK memiliki tujuan yaitu meningkatkan kualitas dan daya 
saing sumber daya manusia Indonesia, oleh karena itu pemerintah memandang perlu dilakukan revitalisasi sekolah menengah kejuruan/madrasah aliyah kejuruan sesuai dengan Instruksi Presiden Republik Indonesia Nomor 9 Tahun 2016 melalui penyempurnaan dan penyelarasan kurikulum dengan kompetensi sesuai kebutuhan pengguna lulusan, peningkatan jumlah dan kompetensi bagi pendidik dan tenaga kependidikan, peningkatan kerja sama antar kementerian/lembaga, pemerintah daerah, dan dunia usaha/industri, peningkatan akses sertifikasi lulusan, dan program lainnya.

SMK sebagai salah satu jenjang pendidikan vokasi yang memiliki tujuan untuk menghasilkan tenaga kerja terampil yang memiliki kemampuan sesuai dengan kebutuhan dunia usaha/ industri dan mampu mengembangkan potensi diri dalam mengadopsi dan beradabtasi dengan perkembangan ilmu pengetahuan, teknologi dan seni.Selain membentuk lulusan yang disiap bekerja di dunia usaha dan dunia industri SMK juga dipersiapkan untuk dapat menciptakan lapangan pekerjaan baru sesuai dengan keahliannya masing-masing. Untuk merealisasikan tujuan tersebut, pemerintah kemudian mengatur kegiatan pembelajaran melalui peraturan menteri pendidikan dan kebudayaan Republik Indonesia No. 34 tahun 2018, yang membahas tentang standar nasional pendidikan SMK/MAK yang mencakup Standar Kompetensi Lulusan, Standar Isi, Standar Proses Pembelajaran, Standar Penilaian Pendidikan, Pendidik dan Tenaga Kependidikan, Sarana dan Prasarana, Pengelolaan dan Biaya Operasi.

Sebagai acuan dalam penyelenggaraan pembelajaran di SMK/MAK pemerintah melalui Peraturan Direktur Jenderal Pendidikan Dasar dan Menengah Kementerian Pendidikan dan Kebudayaan No. 07/D.D5/KK/2018 menetapkan Struktur Kurikulum Sekolah yang memuat Muatan Nasional, Muatan Kewilayahan dan Muatan Peminatan Kejuruan yang terdiri atas dasar bidang keahlian, dasar program keahlian dan kompetensi keahlian.

Bidang keahlian SMK terdiri dari 9 bidang keahlian yaitu teknologi dan rekayasa, energi dan pertambangan, teknologi komunikasi dan informasi, kesehatan dan pekerjaan sosial, Kemaritiman, bisnis dan manajemen, pariwisata, dan seni dan industri kreatif. Untuk Sembilan bidang keahlian tersebut dibagi kedalam beberapa program dengan kompetensi sesuai dengan keahlian masingmasing.

\section{Kemampuan Matematik Lulusan SMK}

Istilah kompetensi sudah menjadi perbincangan lama, mulai dari era Plato atau lebih jauh lagi pada masa Hammurabi yang disebutkan dalam hammurabi code, hingga istilah ini berlanjut sampai abad ke enam belas diadopsi dalam bahasa Inggris, Perancis, dan Belanda (Mulder, Weigel, \& Collins, 2007). Mulder, Weigel, \& Collins (2007) menjelaskan bahwa Plato memaparkan kompetensi sama dengan kata Ikanótis dari bahasa Yunani yang artinya kemampuan untuk melakukan sesuatu atau keterampilan, perkembangan selanjutnya kompetensi dipakai dalam lembaga pendidikan seperti vokasi, dimana kompetensi diartikan sebagai konsep yang fokus pada tujuan dan isi pembelajaran yang bermakna dalam perkembangan kepribadian siswa dengan memiliki pengetahuan yang baik sehingga mampu bekerja secara efektif dalam lingkungannya.

Dalam hal kompetensi tersebut, lulusan SMK dituntut untuk memiliki kompetensi yang dijabarkan dalam tiga dimensi yaitu sikap, pengetahuan dan 
keterampilan. Dimensi sikap direpresentasikan dengan beriman dan bertakwa kepada Tuhan YME, berkarakter jujur, bertanggungjawab, pembelajar sejati sepanjang hayat, dan sehat jasmani dan. Dimensi pengetahuan dijelaskan dengan lulusan yang memiliki pengetahuan faktual, konseptual, prosedural, dan metakognitif pada tingkat teknis, spesifik, detil, dan kompleks berkenaan dengan ilmu pengetahuan, teknologi, seni, budaya, dan humaniora serta mampu mengaitkan pengetahuan di atas dalam konteks diri sendiri, keluarga, sekolah, masyarakat dan lingkungan alam sekitar, bangsa, negara, serta kawasan regional dan internasional.

Hal tersebut tertuang dalam Peraturan Menteri Pendidikan dan Kebudayaan Republik Indonesia Nomor 20 Tahun 2016 tentang Standar Kompetensi Lulusan Pendidikan Dasar dan Menengah, dimana peraturan ini digunakan sebagai acuan utama pengembangan standar isi, standar proses, standar penilaian pendidikan, standar pendidik dan tenaga kependidikan, standar sarana dan prasarana, standar pengelolaan, dan standar pembiayaan.

Sedangkan dimensi keterampilan berkaitan dengan keterampilan berpikir dan bertindak kreatif, produktif, kritis, mandiri, kolaboratif, dan komunikatif melalui pendekatan ilmiah sebagai pengembangan dari yang dipelajari di satuan pendidikan dan sumber lain secara mandiri. Dari ketiga kompetensi generik tersebut dijelaskan kedalam empat kompetensi inti yaitu spiritual, sosial, pengetahuan dan keterampilan, dimana kompetensi inti spiritual dan sosial adalah manifestasi dari dimensi sikap dengan harapan agar menjadi manusia seutuhnya.

Kompetensi matematika juga merupakan wujud kompetensi umum yang berada pada literasi sebagaimana pada peraturan menteri. Kompetensi matematika juga termasuk salah satu kompetensi dasar yang harus dimiliki oleh lulusan SMK. Hal tersebut tertuang pada standar isi yang membuat bahwa kompetensi lulusan SMK untuk mata pelajaran matematika berada di area literasi yaitu memiliki pemahaman matematika dalam melaksanakan tugas sesuai dengan keahliannya. Sub Kompetensi Lulusan SMK untuk matematika yaitu Berfikir matematis yang berkaitan dengan bidang kerjanya, menggunakan pengetahuan faktual, konseptual dan prosedural matematika dalam penyelesaian masalah yang berkaitan dengan bidang keahliannya secara logis, kritis dan kreatif serta mengevaluasi ketepatan dana kebenaran penyelesaian permasalahan yang berkaitan bidang keahliannya menggunakan matematika dasar, mengkomunikasikan hasil penyelesaian permasalahan yang berkaitan dengan bidang keahliannya baik secara lisan dan tulisan secara sistematis.

\section{Kemampuan Matematika dan Dunia Kerja}

Kemampuan matematika merupakan kompetensi dasar yang sangat dibutuhkan dalam dunia industri. Hal tersebut dapat dilihat pada berbagai penelitian menyimpulkan bahwa kemampuan matematik sangat dibutuhkan dalam dunia industri (FitzSimons, 2002). Dibandingkan kemampuan matematika di dunia pendidikan, kemampuan matematika di dunia kerja lebih bersifat aplikatif dan kontekstual. Kemampuan matematika tersebut berkembang sesuai dengan pemahaman dan perilaku pekerja terhadap penyelesaian masalah tertentu dengan pendekatan matematis. Wake (2014) menyatakan bahwa di sekolah, matematika merupakan objek penelitian, sedangkan di tempat kerja, matematika digunakan sebagai alat untuk meningkatkan produktivitas pada lantai produksi atau di tempat 
kerja. Wake (2014) menambahkan matematika di tempat kerja mengambil formulasi yang berbeda dari yang biasa digunakan di sekolah karena perannya yang sangat berbeda dan juga karena pengaruh penggunaan beragam teknologi yang digunakan.

\section{METODE PENELITIAN}

Metode yang digunakan dalam penelitian ini adalah metode penelitian deskriptif kualitatif. Penelitian deskriptif kualitatif ditujukan untuk mengetahui apa yang terjadi dilingkungan dibawah pengamatan, seperti apa pandangan partisipan yang berada di latar penelitian dan seperti apa peristiwa atau aktifitas yang terjadi di latar penelitian (Emzir, 2017). Data diambil melalui wawancara kualitatif menggunakan pertanyaan penelitian di samping observasi kebeberapa bagian di perusahaan maupun sekolah, yang disampaikan secara deskriptif untuk menjelaskan situasi atau peristiwa tertentu (Morissan, 2014).

\section{Partisipan}

Penelitian ini melibatkan stakeholder dari sekolah menengah kejuruan (SMK) dan industri, dari sekolah yaitu pimpinan Sistem Penjamin Mutu Internal (SPMI) sekolah, sedangkan perusahaan Pimpinan (SDM) Sumber Daya Manusia pada perusahaan industri baja di kota Cilegon. Terdapat 2 (Dua) Pimpinan SPMI Sekolah yang akan menjadi informan yang merupakan sekolah unggulan versi Pembina Sekolah Menengah Kejuruan tahun 2018, dan 4 (Empat) Pimpinan SDM di industri manufaktur baja kota Cilegon.

\section{Pengumpulan Data}

Data yang diambil dengan teknik wawancara (Interview), observasi dan dokumentasi. Pengambilan data dilakukan dengan melalui wawancara langsung dengan tujuan untuk mengidentifikasi kebutuhan lulusan di sekolah dan kebutuhan industri. Observasi digunakan untuk mengetahui kondisi lulusan SMK secara langsung di dunia keja. Observasi merupakan teknik ini sangat relevan digunakan dalam penelitian yang meliputi pengamatan kondisi interaksi, tingkah laku. Pengamatan dapat dilakukan secara bebas dan terstruktur. Sedangkan Dokumentasi digunakan untuk melengkapi penelitian, baik berupa sumber tertulis, film, gambar (foto) dan data statisik yang semua itu menberikan informasi bagi proses penelitian.

\section{Analisis Data}

Penelitian ini adalah penelitian deskriptif, dengan lebih banyak bersifat uraian dari hasil wawancara dan observasi serta studi dokumentasi. Data yang telah diperoleh akan dianalisis secara kualitatif serta diuraikan dalam bentuk deskriptif. Teknik analisis data yang digunakan dalam penelitian ini adalah menggunakan langkah sebagai berikut : Reduksi data adalah proses pemilihan, pemusatan perhatian pada penyederhanaan, pengabstraksian dan transformasi data kasar yang muncul dari catatan-catatan tertulis di lapangan. Penyajian data merupakan kegiatan terpenting yang kedua dalam penelitian kualitatif. Penyajian data yaitu sebagai sekumpulan informasi yang tersusun untuk memungkinkan adanya penarikan kesimpulan dan pengambilan tindakan. Menarik kesimpulan dan verifikasi. Kegiatan pengumpulan data dilakukan untuk mencari arti sebuah penelitian, mencatat keteraturan, pola, penjelasan, konfigurasiyang mungkin, alur 
sebab akibat dan proposisi. Kesimpulan yang semula belum jelas akan meningkat menjadi lebih terperinci.

\section{HASIL DAN PEMBAHASAN}

\section{Kompetensi Matematika di Pendidikan}

Berdasarkan pada peraturan menteri dan observasi di lapangan, dapat dibuat skema kompetensi matematika sebagaimana Gambar 1.

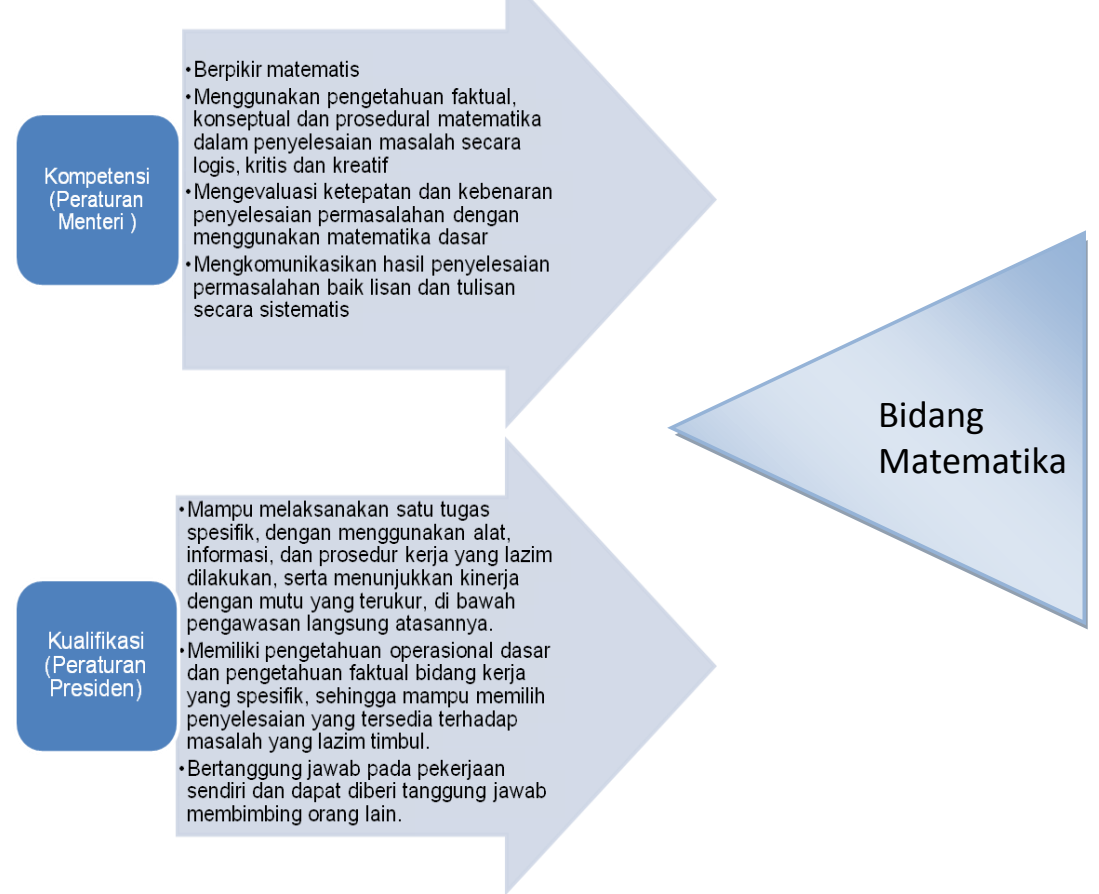

Gambar 1. Kompetensi Matematika

Sumber: Diolah dari Permendikbud Nomot 34 Tahun 2018 Peraturan

Presiden Nomor 8 Tahun 2012 Tentang KKNI

\section{Kemampuan Matematika pada Pekerjaan Industri Manufaktur}

Studi tentang kemampuan matematik untuk bidang tertentu, memberikan respon bahwa kemampuan matematika menjadi dasar dalam mengambil data seperti menulis ukuran maupun dosis dalam lembar kerja, begitu juga kemampuan matematika digunakan dalam memutuskan suatu masalah yang terkait dengan pekerjaan. Di bidang farmasi farmasi, kemampuan matematika sering digunakan dalam pemahaman tentang rasio, proporsi, pengukuran dan prosentasi yang diperlukan untuk persiapan larutan kimia dalam konsentrasi tertentu (Wake \& Yasukawa, 2015).

Sebagaimana ACTRAC/NFITC dalam FitzSimons (2002) menjelaskan bahwa kemampuan matematika atau numerasi digunakan oleh operator dalam melaksanakan aktivitas pada industri farmasi. ACTRAC lebih lanjut menjelaskan bahwa kemampuan matematik diterapkan dalam level $\mathrm{A}, \mathrm{B}$ dan $\mathrm{C}$ sesuai dengan fungsi penggunaan matematika dalam pekerjaan.

Lebih lanjut, penggunaan matematika dapat dilihat pada beberapa aktivitas kegiatan (DEST, 2006) seperti saat mempersiapkan perawatan rutin (technology 
maintenance), menggukana formulasi pada spreadsheet (operator personal computer), menentukan biaya servis dan produk (Cutomer service), Analisis data (Analyst information), membantu mengukur dampak dari perubahan (Support innovation and change), membantu dalam mengukur dan merencanakan target (leader at front line management), menghitung penyesuaian ke layananan pelanggan (quality customer service), membuat perhitungan yang terkait dengan penerapan perubahan (Facilitate and capitalise on change and innovation), menyusun anggaran dan perencanaan keuangan lainnya (budget and financial plan), mengukur kinerja anggaran, menghitung varian dan menyajikan hasil (manage budget and financial plan), mengukur bobot nilai dari interview (recruit and induct staff), menggunakan statistik dan menghitung probabilitas (analyst market data), menganalisis data dan mengambil kesimpulan (forecast market and business needs), melakukan analisis biaya dan manfaat serta melakukan estimasi (Evaluate marketing opportunities), menganalisis data pasar (review marketing performance), membantu merencanakan keuangan (research business opportunities), mendukung operasi bisnis (monitor and manage business operation), memonitor dan melaporkan variasi proses (blow moulding operator), menentukan data, mengolah dan menganalisis data serta melakukan evaluasi hasil (prolem solver using quality tools), mengukur berat, volume dan kapasitas (prepare storage), memonitor level stok(control and order stock), mengukur tinggi, berat dan ukuran barang (load and uload cargo), mengukur porsi, berat dan jumlah dari komposisi material, menghitung tingkat pengenceran untuk antiseptic (provide firt aid), memasukkan data (operator retail equipment), menghitung harga produk (prepare product), mereview hasil penjualan personal (sell product).

Kemampuan matematika digunakan dalam berbagai bidang pekerjaan ditegaskan oleh Hoyles et al. (2002) di mana bidang pekerjaan tertentu membutuhkan kemampuan matematis dalam aktivitasnya, sebagaimana pada Tabel 1.

Tabel 1. Jenis pekerjaan dan Kemampuan Matematika (Hoyles et al., 2002)

\begin{tabular}{|c|c|c|}
\hline No & Bidang Pekerjaan & Penggunaan Kemampuan Matematika \\
\hline 1 & $\begin{array}{l}\text { Electronic Engineering } \\
\text { and Optoelectronics }\end{array}$ & $\begin{array}{l}\text { Mengukur, menghitung dan menggunakan jumlah } \\
\text { secara akurat (dalam desain dan pembuatan } \\
\text { produk), termasuk mengkonversi unit pengukuran. } \\
\text { Kemampuan dalam mengubah objek 2-D dan 3-D. } \\
\text { Kemampuan dalam data statistik untuk (memantau } \\
\text { kualitas produk), Geometri dan trigonometri } \\
\text { (dalam desain bagian kompleks), kemampuan } \\
\text { dalam komunikasi data dan informasi matematika } \\
\text { (dalam tim) dan pemodelan (interaksi berbagai } \\
\text { bagian produk, dan produk tingkah laku) }\end{array}$ \\
\hline 2 & Financial Services & $\begin{array}{l}\text { Kemampuan dalam perhitungan multi-tahap } \\
\text { termasuk persentase, kemampuan untuk } \\
\text { memahami hubungan antara variabel, kemampuan } \\
\text { untuk membaca, menafsirkan dan mengubah data } \\
\text { dari grafik dan spreadsheet, kemampuan untuk } \\
\text { membuat formula, keyakinan dalam }\end{array}$ \\
\hline
\end{tabular}




\begin{tabular}{|c|c|c|}
\hline & & $\begin{array}{l}\text { mengidentifikasi dan menggunakan konsep risiko } \\
\text { dan probabilitas, kemampuan untuk menggunakan } \\
\text { perkiraan, memperkirakan probabilitas formal } \\
\text { untuk memodelkan peristiwa yang mungkin terjadi }\end{array}$ \\
\hline 3 & Food Processing & $\begin{array}{l}\text { Kemampuan untuk membaca, menafsirkan, } \\
\text { mengubah dan mengkomunikasikan data, dalam } \\
\text { bentuk grafik dan angka (dalam memantau dan } \\
\text { meningkatkan efisiensi operasional dari jalur } \\
\text { produksi). Kemampuan untuk memahami } \\
\text { hubungan (termasuk tidak langsung dan multi- } \\
\text { langkah) antara variabel (dalam kontrol stok). } \\
\text { Mengukur, menghitung dan menggunakan } \\
\text { informasi secara akurat (dalam pemeliharaan } \\
\text { mesin), perhitungan perawatan mesin }\end{array}$ \\
\hline 4 & Packaging & $\begin{array}{l}\text { Melakukan pengukuran data statistik dengan data } \\
\text { terdistribusi normal, membuat pemodelan } \\
\text { kompleks dari informasi numerik dan kategoris, } \\
\text { termasuk hubungan linier dan non-linear (untuk } \\
\text { biaya pekerjaan), melakukan komunikasi data } \\
\text { (untuk meningkatkan efisiensi operasional) }\end{array}$ \\
\hline 5 & Health Care & $\begin{array}{l}\text { Melakukan perhitungan cepat dalam perawatan } \\
\text { kesehatan berdasarkan model, melakukan } \\
\text { komunikasi data (grafik, angka), melakukan } \\
\text { perhitungan mental dan keterampilan visualisasi, } \\
\text { menggunakan statistik distribusi normal (untuk } \\
\text { menetapkan rentang normal untuk peralatan } \\
\text { analitik baru), membuat representasi data } 2 \text { dan } 3 \\
\text { dimensi (sebagian besar dalam bentuk grafik } \\
\text { khusus untuk praktik, bukan representasi grafis } \\
\text { umum), menggunakan tes analitik secara manual } \\
\text { dengan perhitungan sederhana yang } \\
\text { mensubstitusikan nilai ke dalam formula aljabar }\end{array}$ \\
\hline 6 & Pharmaceuticals & $\begin{array}{l}\text { Menggunakan statistik data terdistribusi secara } \\
\text { normal dan tren data (korelasi antara sampel } \\
\text { kimia, dan dalam variasi waktu sampel individu), } \\
\text { memahami dan bekerja dengan jumlah dan } \\
\text { proporsi (konsentrasi dan pengenceran), } \\
\text { memahami eksponensial dan kekuatan, melakukan } \\
\text { komunikasi dari informasi matematika dan statistic }\end{array}$ \\
\hline 7 & Tourism & $\begin{array}{l}\text { Menghitung dan memantau variabel yang dapat } \\
\text { diukur (dari kinerja hotel) pemodelan (merancang } \\
\text { dan memelihara model untuk tarif kamar), } \\
\text { mengidentifikasi tren secara statistik. Menghargai } \\
\text { dan menggunakan konsep risiko dan probabilitas } \\
\text { (informal), desain dan biaya investasi modal } \\
\text { Kalkulasi dan perkiraan mental yang cepat }\end{array}$ \\
\hline
\end{tabular}




\section{Materi Kompetensi Matematika di Sekolah dan Kebutuhan Industri}

Materi dari kompetensi matematika yang diajarkan oleh pendidikan SMK sebagian besar digunakan dalam bidang pekerjaan tertentu sebagaimana pada gambar. Namun, berdasarkan hasil interview dengan bagian HRD perusahaan manufaktur baja di Kota Cilegon, tidak semua materi matematika digunakan dalam pekerjaan industri tersebut. Penggunaan materi matematika hanya sebatas pada penggunaan Bangun datar, ruang dan lingkaran, barisan dan deret bilangan (aritmatika dan geometri), bilangan berpangkat dan logaritma, logika matematika, operasi bilangan, statistika, peluang, persamaan dan pertidaksamaan, linear satu variabel, dua variabel, dan kuadrat (lihat gambar 2).

Hal tersebut dikarenakan lulusan SMK akan masuk pada level operator/pelaksana, dimana semua pekerjaan sudah dijelaskan dalam prosedur kerja. Dalam memahami prosedur yang sudah dilakukan, pelaksana dapat menggunakan pengetahuan angka dan logika matematika tersebut. Untuk pekerjaan yang terkait dengan pekerjaan non-rutin seperti analisis masalah, semua diserahkan kepada superior.

Dengan demikian, materi matematika yang digunakan oleh level pelaksana Industri baja masih sangat terbatas untuk kebutuhan seleksi karyawan, dan pekerjaan masih beroritentasi pada keterampilan pengoperasian mesin maupun alat yang sudah ada dan menjalankan sesuai dengan prosedur kerja yang sudah ditetapkan.

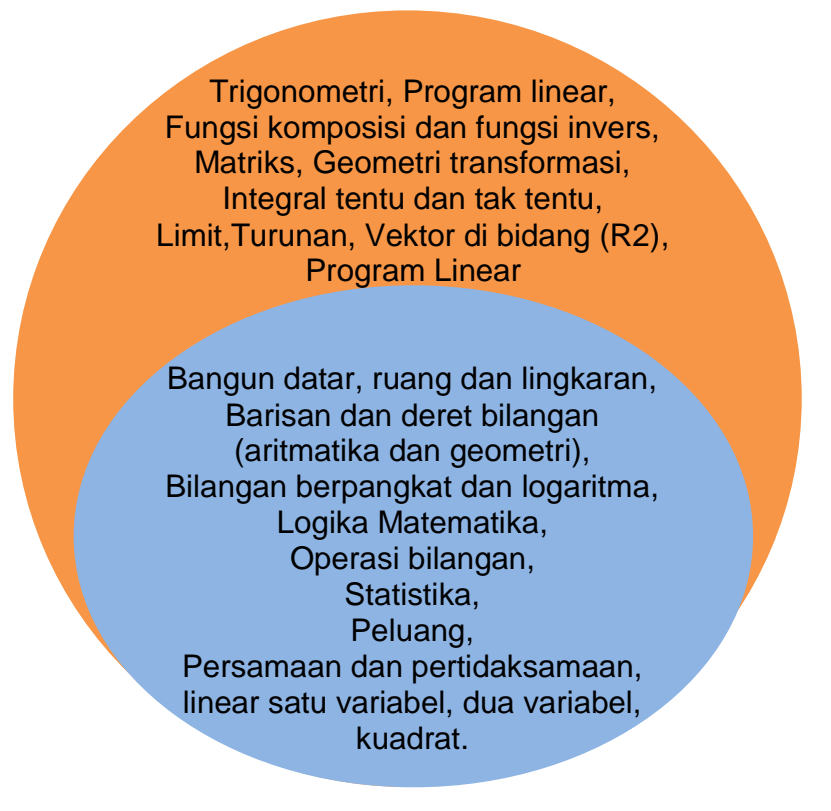

Keterangan: Kompetensi Matematika Sekolah Kompetensi Matematika Dunia kerja

Gambar 2. Perbandingan Materi Matematika yang digunakan

\section{SIMPULAN}

Berdasarkan hasil pembahasan dapat dibuat kesimpulan bahwa materi matematika yang dipelajari di SMK tidak semua digunakan yang digunakan pada dunia industri, terutama industri baja. Pada industri baja, materi yang digunakan adalah pada penggunaan angka dan logika matematika. Hal tersebut dikarenakan 
pekerjaan level pelaksana masih terbatas pada instruksional dan berdasarkan pada standar prosedur yang sudah ditetapkan oleh superior. Hal tersebut menjadi salah satu faktor yang menyebabkan kemampuan kompetensi matematika tidak terlihat di dunia kerja dan kurangnya kesadaran (awareness) pada pekerja dalam kemampuan matematika pada aktivitas yang dilakukan (Nares \& Chahine, 2013).

\section{DAFTAR RUJUKAN}

Agus, A., Awang, A. H., Yussof, I., \& Makhbul, Z. K. M. (2011). The Gap Analysis of Graduate Employees Work Skills in Malaysia. In Proceeding Business and Information (pp. 1-15). Bangkok: International Business Academics Consortium Academy of Taiwan Information System Research.

Ahmad, A. W., \& Shahrill, M. (2014). Improving Post-Secondary Students ' Algebraic Skills in the Learning of Complex Numbers. International Journal of Science and Research, 3(8), 273-279.

Apino, E., \& Retnawati, H. (2017). Developing Instructional Design to Improve Mathematical Higher Order Thinking Skills of Students. In IOP Conf. Series: Journal of Physics: Conf. Series 812 (Vol. 812, pp. 1-7).

Ayonmike, C. ., \& Okeke, B. C. (2016). Bridging The Skills Gap and Tackling Unemployment of Vocational Graduates Through Partnerships in Nigeria. Journal of Technical Education and Training (JTET), 8(2), 1-11.

Calao, L. A., Moreno-Le'on, J., Correa, H. E., \& Robles, G. (2015). Developing Mathematical Thinking with Scratch An Experiment with 6th Grade Students. In G. Conole et al. (Eds.): EC-TEL 2015, LNCS 9307 (pp. 17-27). https://doi.org/10.1007/978-3-319-24258-3-2

Chookittikul, W., Kourik, J. L., \& Maher, P. E. (2011). Reducing the Gap between Academia and Industry: The Case for Agile Methods in Thailand. In Eighth International Conference on Information Technology: New Generations (pp. 239-244). https://doi.org/10.1109/ITNG.2011.49

DEST. (2006). Food Processing Industry Training Package (Vol. 3). Canberra.

Du Plessisis, A., Frederick, H., \& Maritz, A. (2013). Education and training deficits in industrial clusters : Empirical evidence that management can use to rectify the Skills gap in auckland precinct CLUSTERS : EMPIRICAL EVIDENCE THAT MANAGEMENT CAN. Actual Problem of Economics, 2(3), 12-20.

Emzir. (2017). Metodologi Penelitian Pendidikan Kuantitatif dan Kualitatif. Depok: Rajawali Pers.

Fajriyah, L., Nugraha, Y., Akbar, P., \& Bernard, M. (2015). Pengaruh Kemandirian Belajar Siswa SMP Terhadap Kemampuan Penalaran Matematis. Journal on Education, 01(02), 288-296.

FitzSimons, G. E. (2002). What Counts as Mathematics? Technologies of Power in Adult and Vocational Education (1st ed.). Netherland: Springer Netherlands.

FitzSimons, G. E. (2014). Commentary on vocational mathematics education: Where mathematics education confronts the realities of people's work. Educational Studies in Mathematics, 86(2), 291-305. https://doi.org/10.1007/s10649-014-9556-0

Hoyles, C., Wolf, A., Molyneux-Hodgson, S., \& Kent, P. (2002). Mathematical skills in the workplace: final report to the Science Technology and 
Mathematics Council. London. Retrieved from http://eprints.ioe.ac.uk/1565/1/Hoyles2002MathematicalSkills.pdf

Morissan, M. (2014). Metode Penelitian Suvei (2nd ed.). Jakarta: Kencana Prenadamedia.

Mulder, M., Weigel, T., \& Collins, K. (2007). The concept of competence in the development of vocational education and training in selected EU member states: A critical analysis. Journal of Vocational Education and Training, 59(1), 67-88. https://doi.org/10.1080/13636820601145630

Nindiasari, H., Kusumah, Y., Sumarmo, U., \& Sabandar, J. (2014). Pendekatan Metakognitif untuk Meningkatkan Kemampuan Berpikir Reflektif Matematis Siswa SMA. Edusentris, Jurnal Ilmu Pendidikan Dan Pengajaran, 1(1), 8090.

Peraturan Direktur Jenderal Pendidikan Dasar dan Menengah Kementerian Pendidikan dan Kebudayaan No. 07/D.D5/KK/2018. (2018), (021), 307.

Peraturan Menteri Pendidikan dan Kebudayaan Republik Indonesia Nomor 20 Tahun 2016 Tentang Standar Kompetensi Lulusan Pendidikan Dasar dan Menengah (2016).

Saragih, S., \& Winmery L. Habeahan. (2014). The Improving of Problem Solving Ability and Students ' Creativity Mathematical by Using Problem Based Learning in SMP Negeri 2 Siantar. Journal of Education and Practice, 5(35), $123-133$.

Wake, G. (2014). Making sense of and with mathematics: The interface between academic mathematics and mathematics in practice. Educational Studies in Mathematics, 86(2), 271-290. https://doi.org/10.1007/s10649-014-9540-8

Wake, G., \& Yasukawa, K. (2015). Mathematics Education in and for Work. In S. J. Cho (Ed.), The proceedings of the 12th International Congress on Mathematical Education - Intellectual and Attitudinal Challenges (p. 406). Soul: Springer Open.

Williams, J. S., Wake, G. D., \& Boreham, N. C. (2001). School or college mathematics and workplace practice: An activity theory perspective. Research in Mathematics Education, 3(1), 69-83. https://doi.org/10.1080/14794800008520085

Zaenab, S. (2015). Analisis Kemampuan Penalaran Matematis Siswa Melalui Pendekatan Problem Posing di Kelas X IPA 1 SMA Negeri 9 Malang. Jurnal Inovasi Pembelajaran, 1(1), 90-97. 